\title{
Properties of MnO doped graphene synthesized by co-precipitation method
}

\author{
M. Ilman Nur Sasongko ${ }^{3}$, Poppy Puspitasari, ${ }^{1,2}$,

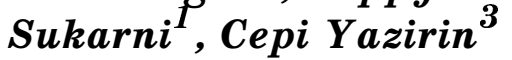 \\ ${ }^{1}$ Mechanical Engineering Department, Engineering Faculty, Universitas \\ Negeri Malang, Semarang Street No. 5, Malang, East Java, Indonesia \\ ${ }^{2}$ Center of Advanced Materials, Universitas Negeri Malang, Semarang \\ Street No. 5, Malang, East Java, Indonesia, 65140 \\ ${ }^{3}$ Master Student, Postgraduate Program, Universitas Negeri Malang, \\ Semarang Street No. 5, Malang, East Java, Indonesia
}

Received August 18, 2018

\begin{abstract}
MnO doped graphene specimens were synthesized using a simple and cost-effective method, i.e. co-precipitation. The characterization of specimens was done through various techniques, such as X-ray Diffraction (XRD), Scanning Electron Microscopy (SEM), and Fourier Transform Infrared (FTIR). Single phase pattern on [222], crystallite size, and $d$-spacing were confirmed by XRD results. The nanostructure morphology was observed using SEM. FTIR showed the shifted peaks and changes in the intensity of molecular bonds of the material. The specimens were sintered for $1 \mathrm{~h}$ at various temperatures of $500{ }^{\circ} \mathrm{C}, 600{ }^{\circ} \mathrm{C}$, and $700{ }^{\circ} \mathrm{C}$. The XRD characterization showed that sintering at $700{ }^{\circ} \mathrm{C}$ resulted in $\mathrm{MnO}$ and $\mathrm{GO}$ peaks with the highest intensity, but the specimen sintered at $600{ }^{\circ} \mathrm{C}$ had the best grain size of $70.39 \mathrm{~nm}$. The morphology characterization by SEM showed a change of shape from triangle to nanosphere with agglomeration. The results of FTIR showed that the shifts in $\mathrm{C}-\mathrm{O}$ and $\mathrm{Mn}-\mathrm{O}$ groups were followed by an increase in $\mathrm{N}-\mathrm{H}, \mathrm{C}-\mathrm{H}$, $\mathrm{C}=\mathrm{O}$, $\mathrm{C}-\mathrm{O}$, and $\mathrm{Mn}-\mathrm{O}$. The results of this study suggest that single-phase $\mathrm{MnO}$ doped graphene was successfully synthesized using the co-precipitation method.
\end{abstract}

Keywords: characterization, co-precipitation, graphene, $\mathrm{MnO}$, synthesis.

Образцы графена с примесью $\mathrm{MnO}$ синтезированы с использованием простого и экономически эффективного метода совместного осаждения. Характеристика образцов проводилась с помощью различных методов, таких как рентгеновская дифракция (XRD), сканирующая әлектронная микроскопия (SEM) и инфракрасное преобразование Фурье (FTIR). Однофазный состав в направлении [222], размер кристаллитов и $d$-интервал подтверждены результатами XRD. Морфологию наноструктур наблюдали с использованием SEM, FTIR показал сдвинутые пики и изменения интенсивности молекулярных связей материала. Образцы спекали в течение 1 часа при различных температурах $500{ }^{\circ} \mathrm{C}, 600{ }^{\circ} \mathrm{C}$ и $700{ }^{\circ} \mathrm{C}$. Характеристика XRD показала, что спекание при $700{ }^{\circ} \mathrm{C}$ приводило к максимальным пикам $\mathrm{MnO}$ и $\mathrm{GO}$, но образец, спеченный при $600{ }^{\circ} \mathrm{C}$, имел лучший размер зерна 70,39 нм. Характеристика морфологии SEM показала изменение формы от треугольника до наносферы с агломерацией. Результаты FTIR свидетельствуют, что сдвиги в группах C-O и $\mathrm{Mn}-\mathrm{O}$ сопровождались увеличением $\mathrm{N}-\mathrm{H}, \mathrm{C}-\mathrm{H}, \mathrm{C}=\mathrm{O}$, $\mathrm{C}-\mathrm{O}$ и Mn-O. Результаты этого исследования доказывают, что однофазный легированный MnO графен был успешно синтезирован с использованием метода совместного осаждения. 
Властивості графена з домішкою $\mathrm{MnO}$, синтезованого методом співосадження. M. Ilman Nur Sasongko, Poppy Puspitasari, Sukarni, Cepi Yazirin

Зразки графена 3 домішкою $\mathrm{MnO}$ синтезовано 3 використанням простого і економічно ефективного методу спільного осадження. Характеристика зразків проводилася за допомогою різних методів, таких як рентгенівська дифракція (XRD), скануюча електронна мікроскопія (SEM) і інфрачервоне перетворення Фур'є (FTIR). Однофазний склад у напрямку [222], розмір кристалітів і $d$-інтервал підтверджено результатами XRD. Mорфологію наноструктур спостерігали з використанням SEM. FTIR показав зсунуті піки і зміни інтенсивності молекулярних зв'язків матеріалу. Зразки спікаються протягом 1 години при різних температурах $500{ }^{\circ} \mathrm{C}, 600{ }^{\circ} \mathrm{C}$ i $700{ }^{\circ} \mathrm{C}$. Характеристика $\mathrm{XRD}$ показала, що спікання при $700{ }^{\circ} \mathrm{C}$ призводило до максимальних піків MnO i GO, але зразок, спечений при $600{ }^{\circ} \mathrm{C}$, мав кращий розмір зерна 70,39 нм. Характеристика морфології SEM показала зміну форми від трикутника до наносфери з агломерацією. Результати FTIR свідчать, що зсуви у групах C-O i Mn-O супроводжувалися збільшенням N-H, C-H, C = O, C-O i Mn-O. Результати цього дослідження показують, що однофазний легований $\mathrm{MnO}$ графен успішно синтезовано з використанням методу спільного осадження.

\section{Introduction}

Over the past few years, the development of alternative materials for high-capacity and eco-friendly energy storage applications has been widely studied. Given the ever-increasing use of fossil fuels, many studies have been conducted to develop energy storage materials for replacing fossil fuels. The use of manganese oxide by far has been broadening as the key ingredient in producing energy storage system due to its good magnetic properties.

Manganese oxide is a manganese mineral that can be found in nature and has naturally formed oxides. Manganese oxide has its uniqueness, such as a very high magnetic moment of $0.326 \mathrm{emu} / \mathrm{g}$ and a grain size of $7.7 \mathrm{~nm}$ [1]. The smaller the grain size, the higher the magnetic properties, meaning that it is suitable for core-shell lithium-ion battery [1]. As described by [2], manganese oxide also has a high purity level, which can be used as an adsorbent for the removal of dyes from textile waste by adsorbing molecules and as a very good cation, i.e. 0.49 a.u. In line with [1], [3] proved that manganese oxide has excellent electrochemical properties $\left(61.43 \mathrm{~F} . \mathrm{g}^{-1}\right)$ and potential use in batteries.

Another material that has been extensively studied for the development of energy storage materials is graphene. Graphene has attracted interest from many researchers due to its unique and remarkable properties and great potential applications in many fields, one of which for alternative energy storage. According to $[4,5]$, graphene oxide is a single graphite oxide sheet with oxygen-containing functionalities bearing on the basal planes and edges. Graphene oxide is obtained by peeling off the graphite oxide. The oxygen functional group can facilitate the modification of the surface of graphene oxide and make it a promising material for composites [6].

In [4] conducted a study on MnO doped graphene, in which graphene was protected by manganese oxide with a very high magnetization of $1.0-10^{3} \mathrm{emu} / \mathrm{m}^{3}$ due to the exchange interactions between impurity ions mediated by $\mathrm{Mn}$. In the study, $\mathrm{MnO}^{4-}$ ions in the $\mathrm{KMnO}_{4}$ electrolyte with three electrons and protons turned into $\mathrm{MnO}$. In [5] conducted a study on the calcination of $\mathrm{MnO}_{2}$ composites and graphene reduction at $500{ }^{\circ} \mathrm{C}$. The research was successful, resulting in a material with a reversible capacity of 900 and $750 \mathrm{mAh}$ that worked well as an active ingredient for lithium-ion batteries. In addition to the two methods, others can be used such as modified Hummers method [6-9], novel and facile method $[10,11]$, coprecipitation methods [12] and so forth.

The co-precipitation method is a very easy method of synthesizing oxide nanoparticles [12]. Moreover, it can result in narrow particle size distributions (Cao, 2004). This method can also improve the crystal structure and properties of the material. The improvement of structure and properties can occur optimally if the synthesis parameters are controlled, such as precursors, material preparation, $\mathrm{pH}$, temperature, stirring speed and time, and surfactant concentration [13].

Sintering is the process of drying and shrinking to obtain a wider surface area and increase the purity of nanomaterials [14-19]. Material that has been synthesized is then characterized to identify changes in properties and purity. Characterization is divided 
into several types, namely X-Ray Diffraction (XRD), Scanning Electron Microscopy (SEM), and Fourier Transform Infrared (FTIR). XRD result confirms single phase pattern, crystallite size, and d-spacing. SEM aims to observe the morphology of nanostructure. FTIR shows the shifted peak and intensity of the molecular bond of the material.

\section{Experimental}

The synthesis was conducted using coprecipitation method. First, 2.9990 gram MnO powder and 0.0010 gram GO were prepared; an analytical balance manufactured by Optima Scale was used for the weighing. The next step was mixing the MnO powder with $30 \mathrm{ml}$ ethylene glycol using a Cimarec II Thermo magnetic stirrer for $1 \mathrm{~h}$. The GO was then added to the mixture while the magnetic stirrer was still spinning, and left stirring for $3 \mathrm{~h}$. The stirring process aimed to mix $\mathrm{MnO}$ and $\mathrm{GO}$ thoroughly. In addition to mixing, stirring also dissolved the $\mathrm{MnO}$ and $\mathrm{GO}$ so that $\mathrm{GO}$ could enter the molecule structure of $\mathrm{MnO}$. After that, the mixture was heated using the magnetic stirrer at $70-80{ }^{\circ} \mathrm{C}$ for $2 \mathrm{~h}$ until it turned into sol. It was washed 4 times with $750 \mathrm{ml}$ distilled water to neutralize the moisture content, monitored using a $\mathrm{pH}$ meter until $\mathrm{pH} 11$ was achieved, and filtered using filter paper. The washing process with distilled water aimed at neutralizing the acid solution. Washing with $\mathrm{NaOH}$ was also done for 3 times. The filter paper used to filter $\mathrm{MnO}$ doped GO was dried in the oven at $120{ }^{\circ} \mathrm{C}$ for 3 hours, aiming to produce a dry powder. The next stage was scraping the residue off the dried filter paper and crushed it for $1 \mathrm{~h}$ to break up the MnO doped GO powder into smaller particles. After crushing, sintering was performed at various temperatures $\left(500{ }^{\circ} \mathrm{C}, 600{ }^{\circ} \mathrm{C}\right.$, and $\left.700{ }^{\circ} \mathrm{C}\right)$ for $1 \mathrm{~h}$ in a tube furnace (MTI corporation). The sintering result was then crushed for $1 \mathrm{~h}$. Scanning electron microscopy (FEI InspectS50) was used for morphological characterization, x-ray diffraction (PANalytical) for phase characterization, and Fourier transform infrared (IR Prestige 21, Shimadzu) for oxide group characterization.

\section{Results and Discussion}

\section{Phase Characterization}

The X-ray diffraction analysis aimed to compare the crystalline phases in the material powder and analyze the properties of the structure, including crystallite size, phase composition, crystal orientation, and

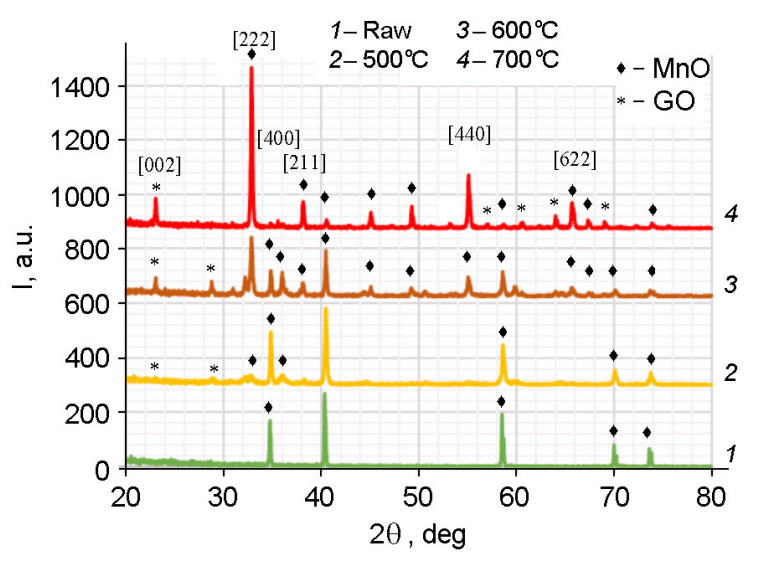

Fig 1. Phase identification of raw $\mathrm{MnO}$ and $\mathrm{MnO}$ doped graphene with different sintering temperatures.

crystal defects in each identification phase. The following is the XRD results of $\mathrm{MnO}$ doped graphene with different sintering temperatures presented in a phase diagram.

Fig 1. shows the structural phase transitions of the four MnO doped graphene specimens sintered at different temperatures. The green(1) graph shows the specimen not subjected to any treatment (raw material), the result of which formed the basis for observing the initial phase changes of those synthesized and sintered at different temperatures. Phase changes occurred after synthesis under sintering temperature variations $\left(500{ }^{\circ} \mathrm{C}, 600{ }^{\circ} \mathrm{C}\right.$, and $\left.700{ }^{\circ} \mathrm{C}\right)$. The different shift of crystalline intensities (as shown in Fig. 1) shows the development of nanoparticles in MnO doped graphene. The development of these nanoparticles indicates an increase in the purity level of MnO doped graphene nanoparticles.

Each phase was characterized by its peaks. Peak [111], [200], [220], [311] and [222] represented the peaks of MnO [2], [20] and [21], while peak [002] represented graphene [6], [22]. The peak that underwent a shift was peak [222]. This could happen because the sintering process was done. The phase growth was caused by the molecular development of MnO-GO during sintering at various temperatures of $500{ }^{\circ} \mathrm{C}, 600{ }^{\circ} \mathrm{C}$, and $700{ }^{\circ} \mathrm{C}$. Peak growth indicates a rapid increase in the purity level of MnO-GO powder. The purity during the sintering process started to increase when the sintering temperature was $500{ }^{\circ} \mathrm{C}$ (as shown in the yellow graph at $40^{\circ}$ ). The increase was shown by index [211], but the increase of GO peaks was not apparent, meaning that the growth of GO was not found in the development of 
Table. Intensity, FWHM, $d$-spacing and Crystallite Size of MnO Doped Graphene Oxide

\begin{tabular}{|c|c|c|c|c|}
\hline \multirow[t]{2}{*}{ Sample Material } & \multicolumn{4}{|c|}{ X-Ray Diffraction (correspond to [222] peak) } \\
\hline & $\begin{array}{c}\text { Intensity } \\
\text { (counts) }\end{array}$ & $\begin{array}{l}\text { FWHM } \\
\text { (degree) }\end{array}$ & $d$-spacing $(\AA)$ & $\begin{array}{l}\text { Crystalline } \\
\text { size }(\mathrm{nm})\end{array}$ \\
\hline Raw Manganese Oxide ( $\mathrm{MnO})$ & 264.33 & 1.03 & 2.23 & 143.44 \\
\hline $\begin{array}{l}\text { Manganese Oxide Doped Graphene Oxide } \\
\text { (MnO-GO) } 500^{\circ} \mathrm{C}\end{array}$ & 277.69 & 2.7 & 2.23 & 54.75 \\
\hline $\begin{array}{l}\text { Manganese Oxide Doped Graphene Oxide } \\
\text { (MnO-GO) } 600^{\circ} \mathrm{C}\end{array}$ & 210.64 & 2.1 & 2.72 & 70.39 \\
\hline $\begin{array}{c}\text { Manganese Oxide Doped Graphene Oxide } \\
\text { (MnO-GO) } 700^{\circ} \mathrm{C}\end{array}$ & 584.58 & 1.7 & 2.72 & 85.05 \\
\hline
\end{tabular}

MnO-GO nanopowder sintered for 1 hour at $500{ }^{\circ} \mathrm{C}$. A very noticeable difference existed in MnO-GO nanopowder sintered at $600{ }^{\circ} \mathrm{C}$ and $700{ }^{\circ} \mathrm{C}$. Under these sintering temperatures, MnO-GO nanopowder gradually showed an increase at $23^{\circ} 2 \mathrm{Th}$ and $33^{\circ} 2 \mathrm{Th}$. At $600{ }^{\circ} \mathrm{C}$, the peak intensity of $\mathrm{MnO}$ and $\mathrm{GO}$ powder increased. As shown by the position of $23^{\circ} 2 \mathrm{Th}$, the specimen sintered at $600{ }^{\circ} \mathrm{C}$ experienced an increase in GO intensity with index [002], i.e. 43.80 cts. The $\mathrm{MnO}$ peak at $33^{\circ} 2 \mathrm{Th}$ and index [222] had an intensity of 210.64 cts. The MnO-GO specimen sintered at a $700^{\circ} \mathrm{C}$ also experienced a similar condition where the intensity of $\mathrm{GO}$ reached 85.90 cts at $23^{\circ} 2 \mathrm{Th}$ and index [002], and that of $\mathrm{MnO}$ reached 584.58 cts at $33^{\circ} 2 \mathrm{Th}$ and index [222]. Peak growth occurred because the atoms present in MnO-GO nanopowder that contain electrons reacted and spread very rapidly. As shown in the graph, the peaks of specimens sintered at $600^{\circ} \mathrm{C}$ and $700^{\circ} \mathrm{C}$ shifted, indicating an increase in the MnO-GO powder successively (Muhammad Ilman Nur Sasongko). The phenomenon showed that a single phase occurred at a $700{ }^{\circ} \mathrm{C}$ and index [222]. Single phase is a straight line pulled above some peak intensities of crystallinity resulted from some variations in the treatment given and showed that the cubic structure centered in the $\mathrm{MnO}$ nanopowders contained electrons in each atom and also a large number in the lattice.

The results of XRD characterization can also determine the crystallite size of MnO-GO material using the following Scherer Equation [23, 24]

$$
d=\frac{K \cdot \lambda}{\beta \cos \theta}
$$

where:

$d$, crystallite diameter; $K$, constant $=$ 0.89-0.9; $\lambda$, wavelength $=1.5406 \AA$; $\beta$, fullwidth half maximum (FWHM)
The results of calculation using the above formula are presented in Table.

Table shows that the crystallite size of specimens sintered at different temperatures. Size variations were affected by the duration of the crushing process, whereas the difference in crystalline purity or intensity was influenced by the variations in sintering time. The size variation was evident in MnO-GO sintered at $700{ }^{\circ} \mathrm{C}$ for $1 \mathrm{~h}$ with the highest purity level of 584.58 and the largest crystal size of $85.05 \mathrm{~nm}$ among the other synthesized specimens. The MnO-GO specimen sintered at $500{ }^{\circ} \mathrm{C}$ had the smallest crystal size of 54.75 , and its purity did not increase significantly. The purity level of raw MnO was $1.33 \%$ higher than MnO-GO at index [211]. The level of purity only increased in $\mathrm{MnO}$, whereas the development of atoms in GO was not visible. The MnO-GO specimens sintered at $600{ }^{\circ} \mathrm{C}$ and $700{ }^{\circ} \mathrm{C}$ experienced different conditions. $\mathrm{GO}$ atoms increased significantly at index [002], and the development of $\mathrm{MnO}$ atoms occurred at index [222]; the longer the sintering time and the higher the temperature (according to the atomic development limit of $\mathrm{MnO}$ ), the higher the purity level (Mohammad Ilman Nur Sasongko). Among the three sintering temperatures, the temperature of $700^{\circ} \mathrm{C}$ generated a specimen with the best purity and size, i.e. a purity level of 584.58 cts and $85.05 \mathrm{~nm}$ in size. It can be concluded that the use of co-precipitation method can produce MnO-GO nanopowder with great purity level and small crystallite size compared to the raw $\mathrm{MnO}$ powder of micron size. XRD test results.

Morphological Characterization

The SEM was used to analyze and compare the morphology of $\mathrm{MnO}$ materials, before and after synthesis [25, 26]. The analysis aimed to examine whether there was any change in the morphology of MnO-GO after undergoing synthesis with different sinter- 


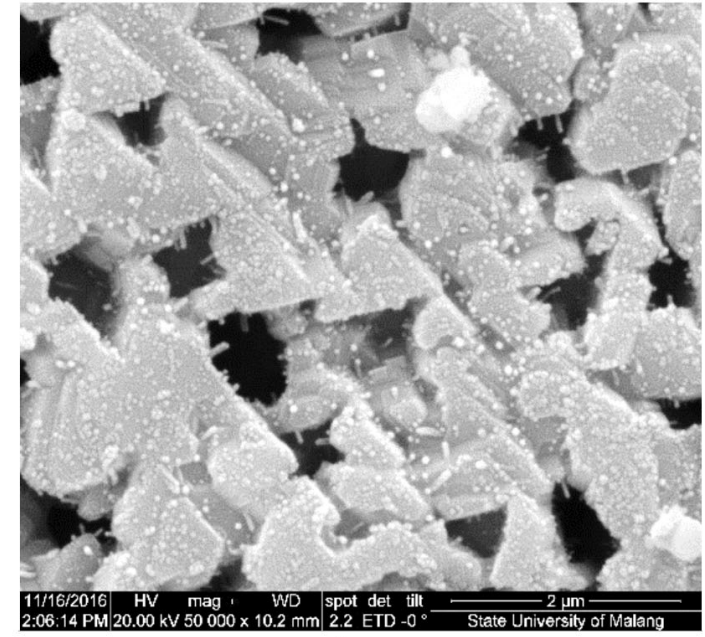

a)

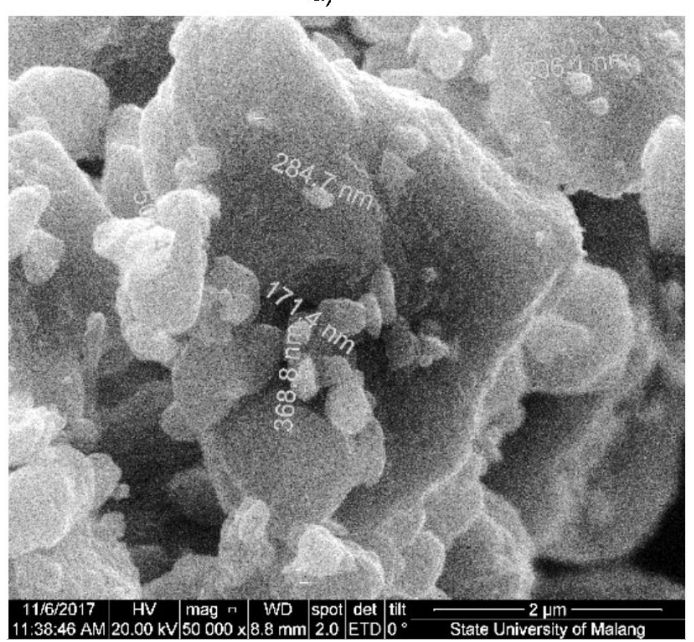

c)

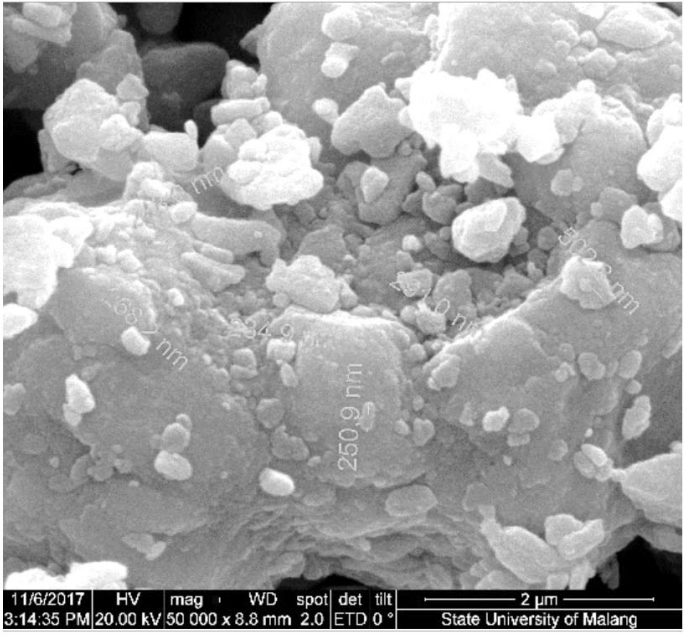

b)

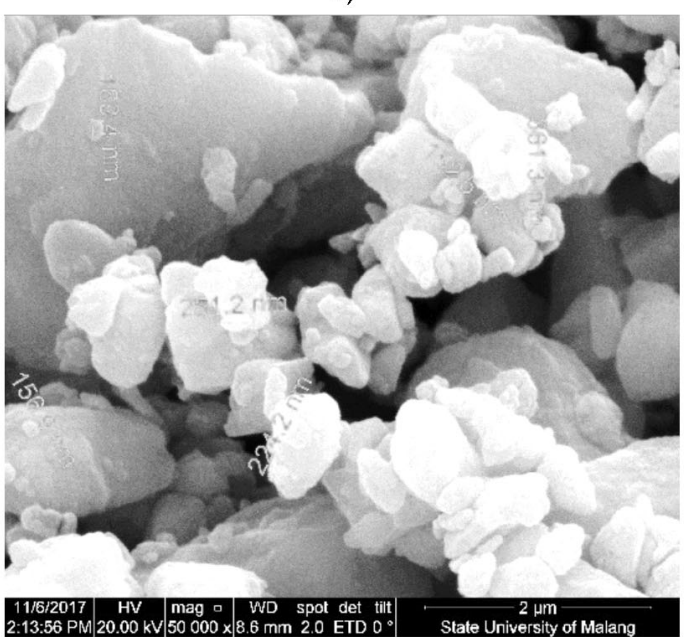

d)

Fig 2. Morphology of manganese oxide (MnO) at 50K magnification: (a) without graphene, (b) $\mathrm{MnO}$ doped graphene with sintering at $500{ }^{\circ} \mathrm{C}$, (c) $\mathrm{MnO}$ doped graphene with sintering at $600^{\circ} \mathrm{C}$, and (d) $\mathrm{MnO}$ doped graphene with sintering at $700{ }^{\circ} \mathrm{C}$.

ing temperatures. Morphological changes that occurred in the synthesized MnO-GO with variations in sintering temperature as the results of SEM are shown in Fig. 2.

The different morphologies of MnO-GO can be seen from the results of SEM at a magnification of $50 \mathrm{~K}$. The results showed morphological changes in $\mathrm{MnO}$ due to variations in sintering temperature. The changes were caused by the use of various sintering temperatures, as stated by [14] that molecular change occurs due to sintering. During sintering, drying and shrinkage are formed due to molecular reactions occurring at room temperature. Under these conditions the mixed materials have many characteristics and MnO-GO which corresponds to the sintering temperature range, starting from $600{ }^{\circ} \mathrm{C}$ to $1000{ }^{\circ} \mathrm{C}$.
Fig. 2a shows the morphology of raw MnO the one that was not synthesized and sintered. The SEM results were obtained by examining the morphology of the raw $\mathrm{MnO}$ at $50 \mathrm{~K}$ magnification. The results showed that the raw MnO was triangular with some parts resembling a trapezium with the smallest size of $65.39 \mu \mathrm{m}$ and the largest size of $91.23 \mu \mathrm{m}$. The difference in the grain size and shape on the surface indicates that agglomeration occurred as particles deposited in the membrane of the $\mathrm{MnO}$ grains. The MnO specimens were tested using SEM to determine the initial size of $\mathrm{MnO}$ powder prior to synthesis.

As shown in Fig. 2b, the morphological changes in MnO-GO after being sintered at $500{ }^{\circ} \mathrm{C}$ could be analyzed from the results of SEM at a magnification of 50K. After the synthesis process, the initial shape of raw 


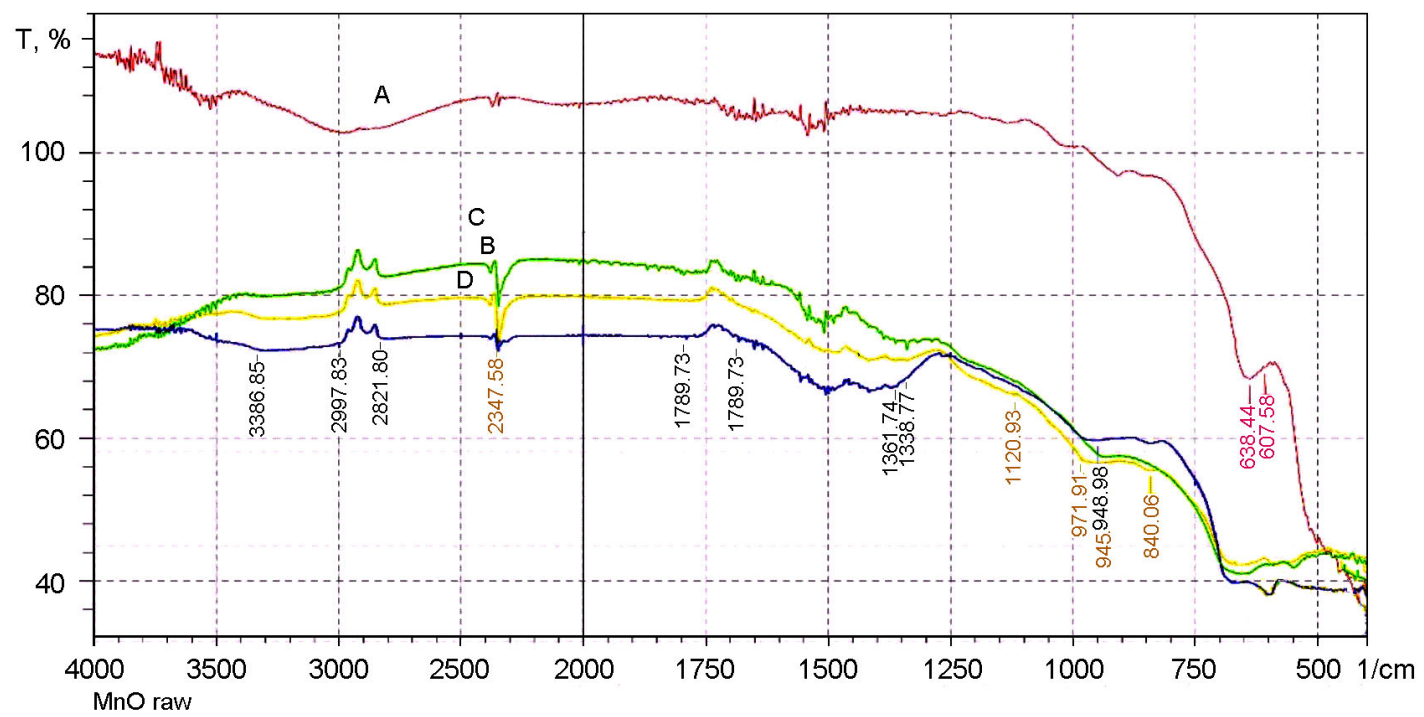

Fig. 3. Difference in oxide groups of manganese oxide $(\mathrm{MnO})$ doped graphene powder (a) without graphene, (b) $\mathrm{MnO}$ doped graphene with sintering at $500{ }^{\circ} \mathrm{C}$, (c) $\mathrm{MnO}$ doped graphene with sintering at $600{ }^{\circ} \mathrm{C}$, and (d) $\mathrm{MnO}$ doped graphene sintering at $700{ }^{\circ} \mathrm{C}$.

MnO (triangular with little dots) turned into spheres with uneven agglomeration. The sphere size was not uniform at some parts of the surface of MnO-GO specimen sintered at $500{ }^{\circ} \mathrm{C}$; the largest one was $234.9 \mathrm{~nm}$, while the smallest was $502.8 \mathrm{~nm}$. The changes were influenced by the sintering temperature $\left(500{ }^{\circ} \mathrm{C}\right)$ and the duration of the crushing process. The morphological changes shown in Fig. 2a and $2 \mathrm{~b}$ indicate that the synthesis had been successfully done.

The results of SEM at 50K magnification (as shown in Fig. 2c) showed an insignificant change in the MnO-GO morphology as a result of sintering at $600{ }^{\circ} \mathrm{C}$, if compared to the one sintered at $500{ }^{\circ} \mathrm{C}$. However, larger agglomeration occurred in MnO-GO sintered at $600{ }^{\circ} \mathrm{C}$. The uniformity of the grain size was not that different from the MnO-GO sintered at $500{ }^{\circ} \mathrm{C}$. The smallest size was 171.4 $\mathrm{nm}$, and the largest one was $501.4 \mathrm{~nm}$. The changes were affected by the sintering temperature of $600{ }^{\circ} \mathrm{C}$ and the duration of the crushing process. The results indicate that the process of transforming $\mathrm{MnO}$ from micron to nano hah been successfully performed.

Fig. 2d shows that a more considerable difference in agglomeration existed in $\mathrm{MnO}$ sintered at $700{ }^{\circ} \mathrm{C}$ than those sintered at $500{ }^{\circ} \mathrm{C}$ and $600{ }^{\circ} \mathrm{C}$. The agglomeration occurred formed small groups with differences in shape and size. The specimen sintered at $700{ }^{\circ} \mathrm{C}$ had the smallest grain of $152.5 \mathrm{~nm}$ and the largest one of $152.5 \mathrm{~nm}$. The morphological changes were influenced by the sintering temperature $\left(700{ }^{\circ} \mathrm{C}\right)$ and the duration of the crushing process. It can be concluded that the transition of $\mathrm{MnO}$ from micro to nano was successful. Great differences in the size and shape of the grains on the coated surfaces showed that large agglomeration occurred after having been synthesized by sintering at $700{ }^{\circ} \mathrm{C}$. This could occur due to the synthesis method, sintering temperature, uneven crushing, and crushing duration.

Characterization of Oxide Groups

The FTIR analysis was conducted to analyze the oxide clusters in $\mathrm{MnO}$, before and after the synthesis with ariations in sintering temperature $\left(500^{\circ} \mathrm{C}, 600^{\circ} \mathrm{C}\right.$, and $\left.700^{\circ} \mathrm{C}\right)$.

Fig. 3 shows the FTIR spectrum of the MnO specimens; the line $3 a$ represents the raw MnO-GO, and the lines $3 \mathrm{~b}, 3 \mathrm{c}$, and $3 \mathrm{~d}$ represent the $\mathrm{MnO}-\mathrm{GO}$ sintered at $500^{\circ} \mathrm{C}$, $600^{\circ} \mathrm{C}$, and $700^{\circ} \mathrm{C}$, respectively. As shown in Fig. 3, one peak shifted and decreased. N-H group occurred at $3500-3400 \mathrm{~cm}^{-1}$ [27], while an increase in $-\mathrm{OH}$ occured at $3386.85 \mathrm{~cm}^{-1}$ [27]. At $2821.80 \mathrm{~cm}-1$, the $-\mathrm{CH}$ group was stable. An increase in GO due to manganese oxide resulted in an increase in hydroxyl and carbonyl/carboxyl groups. The sintering temperature caused a decrease in $\mathrm{N}-\mathrm{H}$ group and an increase in $-\mathrm{OH}$ and $-\mathrm{CH}$ groups, as shown by the green line [28, 29].

At $1732 \mathrm{~cm}-1, \mathrm{C}=\mathrm{O}$ group decreased consecutively [29]. A decrease occurred in $\mathrm{C}=\mathrm{C}$ group at $1633 \mathrm{~cm}^{-1}$, C-O group at $1361.74 \mathrm{~cm}^{-1}, \mathrm{C}=\mathrm{O}$ epoxide group at $1000 \mathrm{~cm}^{-1}$, 
and CO group at $940-948.89 \mathrm{~cm}^{-1}[27,30]$. The presence of mostly $\mathrm{C}-\mathrm{O}$ and $\mathrm{C}-\mathrm{C}$ groups indicates that graphene oxide began to enter into the lattice of $\mathrm{MnO}$ as shown in $3 \mathrm{~b}-3 \mathrm{~d}$ at $1732 \mathrm{~cm}^{-1}$ to $940 \mathrm{~cm}^{-1}$ [27,29]. It was influenced by the mixing of $\mathrm{MnO}$ and $\mathrm{GO}$ powder and various sintering temperatures $\left(500{ }^{\circ} \mathrm{C}, 600{ }^{\circ} \mathrm{C}\right.$, and $\left.700{ }^{\circ} \mathrm{C}\right)$.

As represented by $3 \mathrm{a}-3 \mathrm{~d}, \mathrm{C}-\mathrm{H}$ group at 665.44-651.94 $\mathrm{cm}^{-1}$ was deformed due to sintering and ethylene glycol as a binder [27]. At 638.44-607.58 $\mathrm{cm}^{-1}$, the specific vibrations of $\mathrm{Mn}-\mathrm{O}$ bonds could be superposed $[30,31]$. The positions of $472.56 \mathrm{~cm}^{-1}$ to $418.55 \mathrm{~cm}^{-1}$ included at $\sim 500$, where its intensity decreased with the increase of $\mathrm{MnO}$ content [30-32]. [31] also explained that high $\mathrm{MnO}$ content existed at $418.55 \mathrm{~cm}^{-1}$ to $638.44 \mathrm{~cm}^{-1}$.

\section{Conclusions}

The results of phase characterization obtained from XRD have led us to conclude that the sintering process at $700^{\circ} \mathrm{C}$ for $1 \mathrm{~h}$. produced the best MnO-GO among other treatments, i.e. sintering $500^{\circ} \mathrm{C}$ and $600^{\circ} \mathrm{C}$. The XRD analysis showed that the MnO-GO sintered at $700^{\circ} \mathrm{C}$ was a single phase with the highest intensity of 584.58 counts in $\mathrm{MnO}$ and 85.90 counts in GO. The crystallite size was $85.05 \mathrm{~nm}$, but still a nanometer-scale particle.

The morphology of raw MnO was triangular, and MnO-GO was in the form of nanospheres. The morphological difference showed a change from micro to nano at $50 \mathrm{~K}$ magnification. The MnO-GO sintered at $700^{\circ} \mathrm{C}$ had the smallest crystallite size of $152.5 \mathrm{~nm}$ and the largest crystallite size of $361.3 \mathrm{~nm}$. The MnO-GO sintered at $500^{\circ} \mathrm{C}$ had the smallest crystallite size of $234.9 \mathrm{~nm}$ and the biggest crystallite size of $502.3 \mathrm{~nm}$. The MnO-GO sintered at $600^{\circ} \mathrm{C}$ had the smallest crystallite size of $171.4 \mathrm{~nm}$ and the largest crystallite size of $501.4 \mathrm{~nm}$.

The results of the FTIR analysis on the oxide groups of the synthesized MnO-GO sintered for various sintering temperatures showed that the shift in $\mathrm{C}-\mathrm{O}$ and $\mathrm{Mn}-\mathrm{O}$ was due to the temperature variations, followed by an increase at $3386.85 \mathrm{~cm}^{-1}, 2821.80 \mathrm{~cm}^{-1}$, $940-1732 \mathrm{~cm}^{-1}$, and $418.55 \mathrm{~cm}^{-1}$ to $638.44 \mathrm{~cm}^{-1}$, i.e. - $\mathrm{OH}, \mathrm{C}-\mathrm{H}, \mathrm{C}=\mathrm{O}, \mathrm{C}-\mathrm{O}$, and $\mathrm{Mn}-\mathrm{O}$. In fact, a difference in temperature was the contributing factor to the characterization of oxide groups; the more varied the temperatures, the more visible the shift and the increase in oxide groups.

\section{References}

1. C. C. Lin, C. J. Chen, R. K. Chiang, J. Cryst. Growth, 338, 152, 2012.

2. B. K. Pandey, A. K. Shahi, R. Gopal, Appl. Surf. Sci., 283, 430, 2013.

3. K. I. Bolotin et al., Solid State Commun., 146, 351, 2008.

4. C. S. Park et al., Appl. Phys. Lett., 102, 2013.

5. G. Zhao et al., J. Mater. Chem. A, 3, 297, 2015.

6. X. Dai, W. Shi, H. Cai, R. Li, G. Yang, Solid State Sci., 27,17, 2014.

7. J. Lim et al., J. Appl. Phys., 113, 18, 2013.

8. W. S. Hummers, R. E. Offeman, J. Am. Chem. Soc., 80, 339, 1958.

9. X. Wu et al., Int. J. Hydrogen Energy, 41, 16087, 2016.

10. F. Cheng et al., Inorg. Chem., 45, 20384, 2006.

11. C. Chen, W. Fu, C. Yu, Mater. Lett., 82, 133, 2012.

12. Himadri B Bohindar and kamla rawat, Design of Nanostructures. 2017.

13. Muflihatun, S. Shofiah, E. Suharyadi, vol. XIX, November, pp. 20-25, 2015.

14. R. C. Cammarata, Mater. Sci., 580, 1996.

15. D. Rubi, J. Fontcuberta, A. Calleja, et. al. Phys. Rev. B - Condens. Matter Mater. Phys., 75, 1, 2007.

16. O. D. Jayakumar, H. G. Salunke, R. M. Kadam, et. al. Nanotechnology, 17, 1278, 2006.

17. W. Liu, X. Tang, Z. Tang, J. Appl. Phys., 114, 12, 2013.

18. P. Sharma et al., Nat. Mater., 2, 673, 2003.

19. S. A. Ahmed, Res. Phys., 7, 604, 2017.

20. R. Wu, J. Qu, Y. Chen, Water Res., 39, 630, 2005.

21. P. Li et al., Ceram. Int., 39, 7773, 2013.

22. Q. Chu et al., Chempluschem, 77, 872, 2012.

23. N. B. Yahya, H. Daud, N. A. Tajuddin, et.al., J. Nano Res., 1, 25, 2010.

24. N. B. Yahya, P. Puspitasari, K. K. K. Koziol, et.al., J. Nano Res., 16, 119, 2012.

25. A. Cahyana and A. Marzuki, Pros. Math. Sci. Forum 2014, 23, 2014.

26. L. M. Corneal, S. J. Masten, S. H. R. Davies, et.al., J. Memb. Sci., 360, 292, 2010.

27. R. Narain, Eng. Carbohydrate-Based Mater. Biomed. Appl. Polym. Surfaces, Dendrimers, Nanoparticles, Hydrogels, 1720, 2010.

28. S. Selvam, B. Balamuralitharan, S. N. Karthick, et.al., Anal. Meth., 8, 7937, 2016.

29. S.-D. Jiang et al., J. Mater. Chem. A, 2, $17341,2014$.

30. H. Li, Y. He, V. Pavlinek, Q. Cheng, P. Saha, and C. Li, J. Mater. Chem. A, 3, , 17165, 2015.

31. I. Ardelean and C. Horea, J. Optoelectron. Adv. Mater., 8, 1111, 2006.

32. L. Zhang, R. Jamal, Q. Zhao, M. Wang, and T. Abdiryim, Nanoscale Res. Lett., 10, 1, 2015. 